\title{
Using Hangman Game Application For The EFL Classroom: It Efficacy for Learners to Master Vocabulary
}

\author{
Nada Nabilah \\ Universitas Negeri Padang \\ email: nadanabila211@gmail.com
}

\begin{abstract}
In this era, technology has taken apart in every platforms, including in educational settings, especially Language Teaching and Learning (LTL). This study purposed to determine that the using MobileAssisted Language Learning (MALL) through Hangman Game as one of the games could significantly gave the effect for English Foreign Language (EFL) learners in Indonesia context to master the vocabulary. The participants of this study were the $10^{\text {th }}$ grades students of SMA Negeri 1 Tebing Tinggi Kab. Serdang Bedagai in academic year 2018/2019 that consist of 20 students. The technique of analysis of that was used at this study were the analysis of qualitative data and the quantitative data. The qualitative data was taken from interview, observation of students' learning process, researcher's note. While, the quantitative data was collected from the mean score of test that given to the learners in PreCycle, Cycle I and Cycle II. The findings of this study found that Hangman Game gave the new achievement for the EFL learners when they were doing the activities of learning process in the class. So this situation made the learners had good motivation during the language teaching and learning process and they also actively and enthusiastically in the class. These things indicated that the application Hangman Game could improve the EFL learners' vocabulary mastery.
\end{abstract}

Keywords: vocabulary, MALL, games, hangman game, LTL

\section{Introduction}

Now days, the spread of technology become massive use various aspects of human life. It is also in line with Hoyles and Lagrange (2010) said that the development of digital technology today has given many influences, including the education system which is described as a sign of the integration of technology. For example: teaching language now days cannot be separated with the technology because it can rapidly change how the way teaching and learning process happen in the class. Solanki and Shyamlee1 (2012) and Gilakjani (2017) in their study stated that the existence of technology has helped a lot to the change of language teaching method. It is because it gives many kinds of features that can help the EFL teachers create the interesting teaching language learning (LTL) process in EFL class room. This is very possible because we know that computers or mobile phones have the ability to give the combination among text, video, images, sound even color to make the material more beautiful and the teachers also can create intelligence and then present it to the learners in LTL of EFL classroom.

Fithriani (2018) also stated in her study that technology integration is a tool that also serves to support LTL process in EFL classroom. It is because technology gives positive impact for the learners in learning. NCTM (2000) also argues that there are three positive impacts of the integration of technology for LTL process. First, technology can improve the learning material objectives achievement that will be given to the EFL learners. Second, technology also can increase the effectiveness of teaching and learning process in the EFL classroom. And the last, technology able to influence LTL process that is learned and 
taught to EFL learners in classroom. Ahmadi (2018) also said that by utilizing technology, it will greatly help EFL teachers to improve students' skills during the LTL process in English foreign language classes

According to Paradis (2011), he got from his investigation that the acquisition of English Second Language comes from the vocabulary size of learners. It means that the learners' language mastery ability is closely related to how much vocabulary they have, in this case 'English'. For example in reading skill, the learners need to have many vocabularies in order to make them easier in comprehension of a text that they have read. While in writing skill, the learners use the vocabulary to give a contribution for their writing composition. From the previous explanation it can be conclude that by mastering the vocabulary, the EFL learners can support their skills of language, such as: reading and listening as the receptive skill or speaking and writing as productive skill. Juhendi (2011) thought in his study that one of the vital aspects in language is vocabulary, because it will be needed in every skill when the learners want to master the target language. That is the reason, why the learners who have lack vocabulary will faced by the difficulties to reach their language acquisition.

Vocabulary is one of the tools in language acquisition to achieve the target language. However, the problem of mastering the vocabulary of EFL students is still faced by most of the teachers and students in the EFL class until now. Mbato (2013) states that the effectiveness of EFL learning is one of the success factors for language learning (LTL) itself. This happens because most students find it difficult to understand the material taught by the teacher in English class and one of the reasons is that they only have a small amount of vocabulary. The thing we have to pay attention to is that it is easy for learners to improve their English skills when they all have a large vocabulary. Wilkins quoted in Thornbury (2002) states that by having notes, even though there is a little grammar, there is something we can say, but on the other hand, there is nothing we can say when we do not have vocabulary. This statement explains to us about the importance of vocabulary for us, especially in building good communication with others, because it is impossible for us to communicate well without vocabulary.

In Indonesia, English has become a foreign language and since the beginning of English as a foreign language in Indonesia, at least mastery of vocabulary is one of the reasons why mastery of English in Indonesia is a problem. It is because teachers in Indonesia face challenging in teaching English vocabulary as a foreign language (EFL) context. The result of the observation that I did, I got the information from the teacher showed that there are many challenges in teaching and learning vocabulary process: First, there are differences learning process between L1 vocabulary and target language vocabulary. It is because in learning the foreign language vocabulary is slow. The most of Indonesian EFL teachers also still do not recognize and understand the way to measure the vocabulary of learners and what kinds of words need to be given to learners. Moreover, sometimes the teachers are often complain when their students have lack vocabulary that make them do not easy to know the meaning of the text. The reason why it can happen is because the EFL students do not use whole the vocabulary and use English when they are not the classroom. Second, there are too many types of vocabulary for students to learn. According Folse (2004), said that an educated native speaker will know about 20.000 words or vocabularies. He also stated that students who have many vocabularies will get success in their daily activities. It is because good vocabulary mastery will give contribution to master the language skills, such as listening, writing, reading and speaking. Priyono (2004) also argued that students who just have little of vocabulary will face the problem in learning English.

This problem may be handled with how the teachers and students teaching and learning vocabulary activities and practice of ELT in EFL context. A research that was conducted by Songbatumis (2017) shows that the one of the challenges face by teachers in teaching and learning goal that has to achieved was the students' vocabulary that still less. It is also supported by the argument of Juwita (2019) that said that teacher can use the appropriate technique and practice identifying to help students. Based on this, it can be conclude that to improve the success of LTL process in Indonesia is the English teachers of Indonesia have to try the techniques that appropriate to teach of vocabulary in the class. Because, by 
using the right technique can have a good effect for students to master a foreign language, in this case English.

According to Alqahtani (2015) in his observation, the most of EFL teaching learning process still use the traditional method that teach the learners just focus on teaching grammar than vocabulary itself. It is supported by the thought of Phipps and Borg (2009) said that EFL teachers' cognition has goo ability in teaching grammar but this is contrast with the condition of vocabulary that showed the consideration of the teachers' cognition are still low. And now, we forgot about the aim of learning language is to make us easier to communicate with another person well in communicating by using the target language. As a result, we can see that the most EFL learners in Indonesia are better at grammar but they are lack of vocabulary mastery.

Realizing the importance of mastering vocabulary in order to make learners can master the target language, of course the mastery of vocabulary must be developed. Games now days become a type of the applications in mobile phones that is much use in language teaching learning (LTL) especially in Indonesia. Andrew Wright, Betteridge, Buckby (2006) in their book that entitle "Games for Language Learning" gave their opinion that games can be a helping for the EFL teachers to give a creation in the teaching learning process context. Thornton and Houser (2005) also supported by saying that mobile devise mobile devise is one of the effective tools and also provides many benefits in delivering material in language learning. Half of the Indonesia researchers and English teachers also in the other country have begun using MALL and also the game application to support their language teaching and learning (LTL) practice in English class to reach the English acquisition of EFL learners. So that teachers use MALL as a medium in learning. Mobile learning is an easy-to-use medium for learning languages. According to Fithriani, Dewi, Daulay, Salmiah \& Fransiska (2019), MALL is a tool that can be used to make the LTL process more interesting to support the learning process in the EFL class. Game-based learning is designed as one of the features for mobile learning. Huang et al (2012) argues that the benefits that we can get from mobile technology in language learning, such as: flexibility, small size, cheaper, easy to implement and also user-friendly.

For example is using Hangman Game, this game can help the EFL to build enthusiasm and stimulate them in learning foreign languages, especially vocabulary teaching and learning process. The way to play this game is by guessing letters to reveal a word or phrase. When the player makes a mistake in guessing the letter, a character on screen is "hanged". There are some studies have shown that this game can make the EFL learners more active and they enjoy learning so that they can get their language acquisition. This is in line with the statement of Hidayat, Nadrun and Wahyudin (2015), that the Hangman game can be an alternative for teachers in teaching vocabulary because this game helps increase students' vocabulary mastery. Based on this explanation, it can be concluded that to increase the success of LTL, English teachers in Indonesia need to be more creative and find media of interest in teaching vocabulary. One of them is the Hangman game media because using this media can have a good effect on students' acquisition of foreign language mastery. Because, by doing this it can give good effect for the learners' acquisition in mastery the foreign language. So, based on the explanation above, the objective of this study is to improve student's vocabulary mastery by using Hangman game in an English Foreign Language (EFL) classroom.

\section{Methods}

This study conducted by using Classroom Action Research (CAR) on $12^{\text {th }}$ June 2019 until $26^{\text {th }}$ July 2019. Classroom Action Research (CAR) is a research action that is taken by a teacher in a class where this study used model by Hopskins. This kind of research consist of four steps, they are: (a) planning, the researcher made a lesson plan based on the preliminary study about the problems in the classroom, (b) acting, the researcher implemented Hangman game that had done in two cycles in which in every cycle there were four meetings. The researcher also gave a test in the end of every cycle. The procedures in 
implementing of Hangman are: first, download the application of Hangman game in play store of mobile phone; second, students choose of the categories themes and the level; third, after students do the both of procedures, they can click 'start game' to begin. So, in this activity the students have to guess the word by guessing it letter by letter. When they can guess correctly, the letter will appear automatically and when they are wrong, it will show the elements of Hangman chart. (c) observing, the researcher did an observation to the students during the implementation of the action and wrote it down on notes of teaching learning (d) reflection, so in this stage the researcher not only just gave the feedback of learner's vocabulary mastery but also the process of teaching and learning during the implementation of Hangman Game.

The participants of this study were 20 learners that consist of 15 females and 5 males learners that taking vocabulary learning in the first senior high school at SMA Negeri 1 Tebing Tinggi Kab. Serdang Bedagai. The collecting of data use four instruments: (1) test, (2) observation of students' learning process (3) interview, (4) researcher's note. The purpose of tests given to the participants was to measure the mastery of students' vocabulary The tests given to the participants in this study were 20 multiple choice questions and 10 essay questions. The observation and observation's note are used to collect the data about the participation of learners during the activities in English class. Meanwhile, the instrument of interviews were used to collect the data that concern to the students' experience and also their engagement in using Hangman Game Application, to support their learning process. In this study, the data were analyzed by using; quantitative data to measure the learners' engagement on Hangman Game and qualitative data regarding to learners perceptions on its effectiveness and to give the illustration how the teaching and learning process of Hangman Game.

\section{Result and Discussion}

The data collection will be categorized the findings of this study into three: first: Hangman game effective to learners to master vocabulary, second: The students are active in following English lessons, Third: Hangman Game can increase the learners' learning motivation.

a. Hangman game effective to learners in helping vocabulary master to reach their language acquisition The test that has given by the researcher from the preliminary study, cycle 1 and cycle 2 showed there were an improvement scores that done by the learners in the last of every cycle. Meanwhile the result of the data in interview revealed that Hangman Game can improve the EFL learners' vocabulary because the learners will learn happily and enjoyable that will make the learners indirectly easier to understanding, recognize and memorizing the words that they got in the application. Actually, it is not only in this research, there are also some researches which found the same findings. For example: The study that was conducted by Hidayat, et.al (2015) also showed that this application game, able to help students in increasing their vocabulary. While, In this study the result of the interviews and also the notes of the researcher's observation showed that the most of the EFL learners as the participants felt very helped to add and increase their mastery of vocabulary by using the Hangman Game application in mobile phone. The result of the quantitative data in this study showed that the score of learners in vocabulary test was improved from the pre-cycle, cycle I and the cycle 2 test. The result of the tests showed that there was an improvement from the pre-cycle and Cycle I where the mean of learners score in pre-cycle was 55.00, it means that there were only 3 from 20 learners who could pass the score of standard minimum. And in the Cycle I, it was just about $45 \%$ learners or if we compare there is a slight increase shown by the participants where in this second test there are at least 9 learnerss who can exceed the minimum score. Meanwhile the average value shown in Cycle I is 67.45. Meanwhile in Cycle II there has been a considerable increase where the average score obtained by students is about 81.45 . There were about 16 students or it was about $80 \%$ learners passed the standard minimum score. From the explanation, the study showed that this 
Hangman Game application can be as an effective tool to increase learners' vocabulary mastery. Here is the comparison of test score of vocabulary:

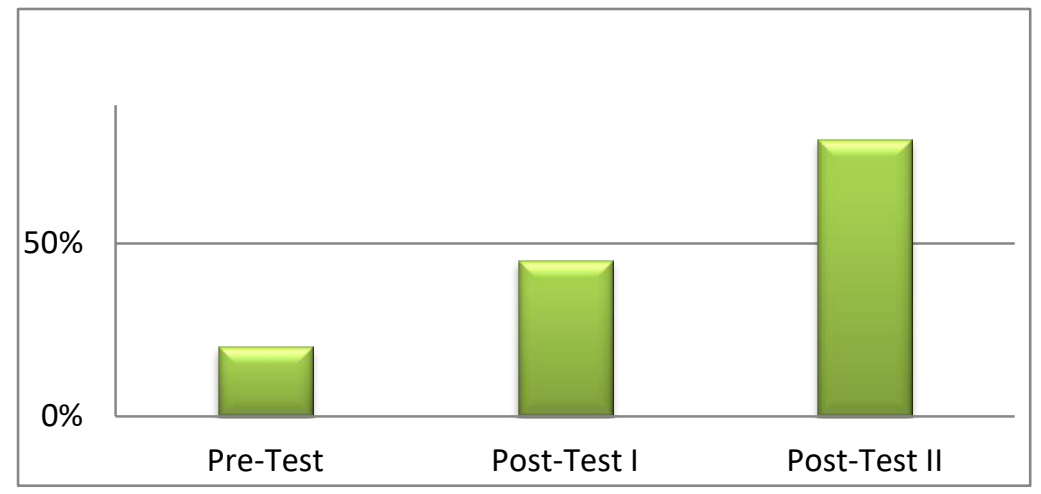

Figure 1. The Percentage of Vocabulary Score Test

b. The students are active in following English lessons

Hangman game also gave a positive impact for the EFL learners in Indonesia for their language acquisition; one of the impacts that I mean is the EFL learners are more active than usual in following English lessons. It is because Hangman game gave a positive impact for the learners because they feel more relaxed and enjoy the activity during the learning vocabulary process. Not only enjoy the activity in the class, also shows an attitude of attention and also focuses on listening to explanations from the teacher in the class during the vocabulary learning. Besides that, students are also more confident to appear and show their abilities such as answering the guessing to reach the language acquisition.

The qualitative data that was taken before, during and after the activities that I got from the results of interviews with students, observation sheets about what I got in class and the researcher's notes at each meeting showed that by applying the Hangman game, the vocabulary learning class could be more effective. The learners also had more motivation, enthusiastic in following the class, and they also active in giving the participation during the LTL process. This is also supported by the result of Ifa Fauziyyah's study (2015) that found teaching English vocabulary through Hangman Game can create an effective English class. It is because Hangman Game encouraged the EFL learners to be more active in following the activity during theLTL process in the class. The result of Prasetiawati's study also showed that using Hangman Game in vocabulary learning class can build an active and corporative class during the TLT.

c. Hangman Game can increase the learners' learning motivation

This media can improve the learners' motivation during the learning in the class. Hangman can also influence students to support and be more motivated so that they show a high enthusiasm in LTL of vocabulary. In the other hand, Hangman Game also makes it easier for teachers to be able to lead the learners during the vocabulary learning process in class so that they are more serious and also feel interested. These findings were gotten from the result of the interviewed that were done before and after the implementing Hangman Game in the class. So, I used this instrument to add the information related to reflect the students' answer about the experience and the effect that they felt during the teaching and learning vocabulary process by using Hangman game.

While based on this, it indicated that learning vocabulary by using Hangman Game is one ways that teachers can do to build the spirit of learners during the LTL process. The study found out that the EFL learners gave good respond in English teaching vocabulary learning process through 
DOI: https://doi.org/10.24036/icolp.v1i1.31

Hangman Game. Here are the detail data that can be presented relate to the result of the using Hangman Game to improve the EFL learners in their vocabulary mastery that is as a tool language acquisition.

Table 1. The Improvement of Pre-Cycle, Cycle I and Cycle II

\begin{tabular}{|c|c|c|}
\hline Before Action & After Cycle I & After Cycle II \\
\hline $\begin{array}{l}\text { The learners did not focus } \\
\text { and serious in noticing } \\
\text { material that was given by } \\
\text { the teacher }\end{array}$ & $\begin{array}{l}\text { Students begun felt interest } \\
\text { to Hangman Game. They } \\
\text { also started competing in } \\
\text { guessing the vocabulary in } \\
\text { the game. In this part the } \\
\text { learners had focused on } \\
\text { following the LTL process. }\end{array}$ & $\begin{array}{l}\text { Learners looked to be more } \\
\text { comfortable and interested in } \\
\text { playing games according to the } \\
\text { teacher's directions. They have good } \\
\text { motivation in finishing the game. }\end{array}$ \\
\hline $\begin{array}{l}\text { The learners were passive } \\
\text { in the class }\end{array}$ & $\begin{array}{l}\text { The learners tried to be } \\
\text { more active in the class } \\
\text { although sometimes felt } \\
\text { shy. }\end{array}$ & $\begin{array}{l}\text { Learners were competed to be active } \\
\text { and participate in vocabulary } \\
\text { learning classes. }\end{array}$ \\
\hline $\begin{array}{l}\text { The learners still looked } \\
\text { confused when playing } \\
\text { Hangman game }\end{array}$ & $\begin{array}{l}\text { The learners had started to } \\
\text { understand how to play the } \\
\text { Hangman game but they } \\
\text { still find it difficult to } \\
\text { guess the vocabulary that } \\
\text { appears }\end{array}$ & $\begin{array}{l}\text { The learners were already able to } \\
\text { enjoy the flow of the vocabulary } \\
\text { learning process by using the } \\
\text { Hangman game that has been } \\
\text { instructed by the researcher }\end{array}$ \\
\hline $\begin{array}{l}\text { The learners' mean score } \\
\text { of the first vocabulary test } \\
\text { was } 55,0\end{array}$ & $\begin{array}{l}\text { The learners' mean score } \\
\text { of second vocabulary test } \\
\text { was } 67,45\end{array}$ & $\begin{array}{l}\text { The learners' mean score of third } \\
\text { vocabulary test was } 81,45\end{array}$ \\
\hline
\end{tabular}

From the table above, it can be seen that there was an improvement in students' vocabulary mastery. It shows from the students' score in vocabulary test from pre-cycle, cycle I and cycle II. Although in the Pre-Cycle, almost all of students still did not reach the minimum scores but they can show that in the Cycle I and Cycle II there was an improvement that they did. From the findings above, it can be seen that there was an improvement of the mean score of the learners. Even though there was no significant improvement. It was just not about the learners' score but also the result of the qualitative data that I collected from observation sheet, the result of interview, and the note I took in every single meeting showed about the condition of the class. It showed that the learners' motivation, participant and their enthusiastic during the LTL of vocabulary Through Hangman Game was improved. This is in line with the finding of a study that was conducted by Ifa Fauziyyah (2015) that shows hangman Game is one of the effective game that can improve the vocabulary of the students. From that, it can be indicated that the use of Hangman Game in the vocabulary class gives good effect for students. Besides that, the students also give good respond for this application.

\section{Conclusion}

In this era globalization, MALL has become a part of media that used to support not only in business but also in education world. It means that the use of technology must be maximized in EFL language learning to reach their target language acquisition. This study finds that MALL, in specific way the use of game applications have great potential for the EFL learners skill in Indonesia context. Furthermore, this study also shows that game application gives efficacy in improving the learners' vocabulary mastery, the effectiveness the EFL learning process and increase the learners' motivation in LTL process. Based on the 
findings that have been explained above, it is recommended that game applications also will give good impact and integrated the EFL learners in Indonesia especially. However, it is also must be noticed that the guidance of teachers also much needed to ensure the use of game application with the aim as a media in teaching and learning set.

\section{Acknowledgments}

I would like to express my sincere gratitude to the English teacher and students as the subjects who were involved a lot in helping me to do this study. The especially a great debt to the headmaster and vice principal of SMA Negeri 1 Tebing Tinggi, who gave me an opportunity to do this study until I can finish the study. Without all of you may be it will very difficult to reach the finish of this study.

\section{References}

Alqahtani. M. (2015). the importance of vocabulary in language learning and how to be taught. International Journal of Teaching and Education, 3(3).

Ahmadi. (2018). The use of technology in English language learning: a literature review. International Journal of Research in English Education, 3(2).

Fauziyah, I, (2015). The effectiveness of using game in increasing students' vocabulary mastery. Thesis. Bandung: Universitas Islam Negeri Sunan Gunung Djati.

Fithriani, R. (2018). Discrimination behind nest and nest dichotomy in ELT professionalism. In the $1^{\text {st }}$ Annual International Conference on Language and Literature. KnE Social Science. p.741. DOI 10.18502/kss.v3i4.1982

Fithriani, R., Dewi, U., Hamidah, S., Salmiyah, M. \& Fransiska, W. (2019). Using facebook in EFL writing class: Its effectiveness from students' perspective. The Second Annual International Conference on Language \& Literature. Medan: Universitas Islam Negeri Sumatera Utara (UINSU). DOI 10.18502/kss.v3i19.4892.

Gilakjani, P. A. \& Sabouri, N. B. (2017). Advantages of using computer in teaching English pronunciation. International Journal of Research in English Education (IJREE), 2(3), 78-85.

Hidayat, E. W. Nadrun. \& Wahyudin. (2015). Increasing vocabulary mastery of the seventh grade students through hangman game. e-Journal of English Language Teaching Society (ELTS), 3(2).

Hoyles, C. \& Lagangre, J. B.(Eds). (2010). Mathematics Education \& Technology Rethinking the Terrain. the $17^{\text {th }}$ ICMI Study. Heidelberg. New York: Springer.

Huang. et al (2012). A ubiquitous english vocabulary learning system: Evidence of active/passive attitudes. p.58.

Johanne. (2011). Individual differences in child english second langugae acquisition: Comparing childinternal and child-external factors. Linguistic Approaches to Bilingualism, vol. 1.

Juwita. (2019). Improving the students' ability in mastering vocabulary by using Feely Bag Game at Grade VII Private Islamic Junior High School Pesantren Dairi. UIN-SU Medan. 
Meriem Webster's Ninth New Collegiate Dictionary. (nd). (online). America: Meriem Webster). Retrieved from http://www.merriam-webster.com/dictionary. Accessed on 3 October 2021.

Phipps, S. \& Borg, S. (2009). Exploring tensions between teachers' grammar teaching beliefs \& practices. System, 37 (3). 380-390.

Priyono. (2004). Logical problems of teaching English as a foreign language in Indonesia. In Cahyono, B. Y. \& Widiati, U. (Eds.), The Tapestry of English Language Teaching \& Learning in Indonesia. p.17-28. Malang: State University of Malang Press.

Solanki, D. \& Shyamlee1, M. P. (2012). Use of technology in English language teaching \& learning: an analysis. International Conference on Language. Medias and Culture IPEDR. Vol.33. p.150-156. Singapore: IACSIT Press.

Songbatumis A.M. (2017). Challenges in teaching english faced by english Teachers at MTsN Taliwang, Indonesa. Journal of Foreign Language Teaching \& Learning, 2(2).

Thornbury. (2002). How to Teach Vocabulary. England: Longman.

Thornton, P. \& Houser, C. (2005). Using mobile phones in English education in Japan. Journal of Computer Assisted Learning. p.21.

Wright, A., Betteridge, D. \& Buckby, M. (2006). Games for language learning. Cambridge University Press. 